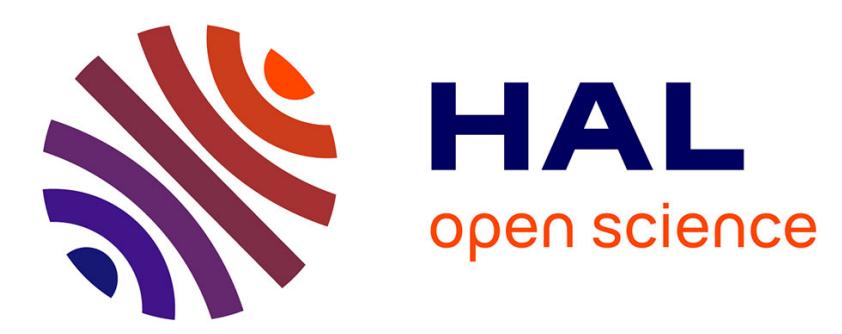

\title{
The PACS and marriage and cohabitation in France
}

Claude Martin, Irène Théry

\section{To cite this version:}

Claude Martin, Irène Théry. The PACS and marriage and cohabitation in France. International Journal of Law, Policy and the Family, 2001, 14 (3), pp.135-158. 10.1093/lawfam/15.1.135 . halshs00199963

\section{HAL Id: halshs-00199963 \\ https://shs.hal.science/halshs-00199963}

Submitted on 3 Jan 2008

HAL is a multi-disciplinary open access archive for the deposit and dissemination of scientific research documents, whether they are published or not. The documents may come from teaching and research institutions in France or abroad, or from public or private research centers.
L'archive ouverte pluridisciplinaire HAL, est destinée au dépôt et à la diffusion de documents scientifiques de niveau recherche, publiés ou non, émanant des établissements d'enseignement et de recherche français ou étrangers, des laboratoires publics ou privés. 


\title{
Article publié dans International Journal of Law, policy and the Family, vol. 14, n ${ }^{\circ}$, p. 135-158
}

\section{The PACS and Marriage and Cohabitation in France}

\author{
Claude Martin \\ chercheur au CNRS et enseignant à l'Institut d'études politiques de Rennes \\ Irène Théry \\ directrice d'études à l'EHESS, Paris
}

\section{Introduction/Abstract}

Change in marriage and cohabitation began in France thirty years ago. 2.5 million cohabiting couples and more than 40 per cent of births outside marriage reveals not only a new acceptability of cohabitation and family formation out of wedlock, but a new social signification of marriage itself. In this paper, we analyse what appears to have been a "soft" revolution, widely accepted, and a paradoxical mutation. While the abandonment of a strictly matrimonial conception of the family is generally accepted in France, attitudes are much more contradictory with respect to legal rights of unmarried couples. The long, complex and controversial story of the evolution of Pacs, shows, behind the issue of homosexuality, how difficult it is for French culture to conceive a legal status for non-married couples. Pacs, as a new possibility for heterosexual as well homosexual cohabitees, is not easy to define from a legal point of view. This intermediary status, neither a union nor a contract, neither private nor public, expresses the ambiguity of the "French way » of responding to increasing cohabitation. Analysing Pacs as a "transitory law »,we suggest that a complex jurisprudential story is now beginning in France. This paper ends with a broader perspective on the interpretation of family change: no consensus exists in academic and political circles. The new forms of social inequalities will certainly represent one of the main issues in the public, academic and political debate in the future.

I. A deep social change in behaviour and values: the Normalization of Heterosexual Cohabitation in France

Roussel (1978) and Gokalp (1981) were among the first to identify a serious change in the way partnerships between couples were being constituted in France. They spoke at that time of "juvenile cohabitation" or "marriage on a trial basis" (mariage à l'essai), to signify the fact that, after the social movements of 1968 , the new generations wanted to delay entering marriage and having children. The emancipation process consisted in sexuality outside marriage and experiencing a love relationship before institutionalizing it. Pregnancy was nevertheless usually considered to be an imperative reason to marry before the birth of a child. It took almost ten years to realise that this phenomenon was not merely a simple postponement of entering marriage and institutionalizing a 
family, but was for a growing number of couples a new way of life. In the 1980s and 1990s, cohabitation became progressively a commonplace, which was connected to the decline of marriage. Thus, increasing numbers of couples decided to begin their conjugal life without marriage, and even to have a first or subsequent children out of wedlock. Unmarried cohabitation is nowadays the normal way to begin a partnership. In the 1960s, only 16 per cent of cohabiting unions began outside marriage. In the 1990s the figure was 87 per cent.

The number of marriages in France has steadily decreased since the end of the 1960s: in 1969 the annual number of marriages was $380,000 \cdot$ This dropped to 253,000 in 1994 , the lowest point since the second world war, with a marriage rate of 4.4 (per 1000). Then there was a slight increase, particularly in 1996 (10 per cent increase), with 280,000 marriages (marriage rate : 4.8) as a direct result of a fiscal reform for non-married parents.i This increase was mainly the consequence of parents marrying in order to legitimize one or several children (37 per cent more than in 1995). Then there was a stable period with only a slight increase in $1997(1.7 \%) ; 282,100$ in 1998 and 285,400 in 1999 , with a marriage rate of 4.8 . This slow but constant recovery of marriage may be seen as a significant tendency in the sense that over the past two years the number of marriages of couples without children, which had decreased constantly from 1972 to 1995, has slightly increased, which may mean that the legitimation of children is less important for the new generations of couples and that marriage is again an attractive institution (Prioux, 2000). Another aspect of this change concerns the proportion of marriages taking place in church. This decreased from 75 per cent at the beginning of the 1970 s to 50 per cent at the beginning of the 1990s. But the most significant feature is probably the delay in age at first marriage. In 1998, women marry on average two years later than in 1990 and five years later than at the end of the 1970s (29.7 years old for men, and 27.7 for women in 1998).iii

However, these transformations of marriage do not mean there has been a rejection of family life or of children. So cohabitation is growing constantly, compensating for the decrease in marriage. 
There were 2.4 million cohabiting couples in 1998, compared to 1.5 million in 1990, which means almost one couple in six in 1998, compared to one in ten in 1990 (Beaumel \& alii, 1999). In 1998 almost half of all cohabitants (1.1 million couples) were living with at least one child (see Table 1).

\begin{tabular}{|c|c|c|c|c|}
\hline & \multicolumn{2}{|l|}{1990} & \multicolumn{2}{|l|}{1998} \\
\hline & (thousands) & $\%$ & (Thousand) & $\%$ \\
\hline Cohabitants & $\begin{array}{l}\text { CohabitantsCo } \\
\text { habitantsCohabit } \\
\text { ants1 } 516\end{array}$ & 10,7 & 2429 & 16,4 \\
\hline Without child & 973 & 6,8 & 1353 & 9,1 \\
\hline One child & 332 & 2,4 & $\mathbf{5 8 7}$ & 4,0 \\
\hline $\begin{array}{ccc}\begin{array}{c}\text { Two } \\
\text { children }\end{array} & \text { or more } \\
\end{array}$ & 210 & 1,5 & 490 & 3,3 \\
\hline Married & $\begin{array}{l}\text { MarriedMarrie } \\
\text { dMarried12 } 714\end{array}$ & 89,3 & 12386 & 83,6 \\
\hline Without child & 6850 & 48,2 & 7211 & 48,7 \\
\hline One child & 2439 & 17,4 & 2126 & 14,4 \\
\hline $\begin{array}{ccc}\begin{array}{c}\text { Two or more } \\
\text { children }\end{array} & \\
\end{array}$ & 3425 & 24,0 & 3049 & 20,5 \\
\hline All together & $\begin{array}{l}\text { All togetherAll } \\
\text { togetherAll } \\
\text { together14 } 229\end{array}$ & 100,0 & 14815 & 100,0 \\
\hline
\end{tabular}

Table 1. Number of couples married and cohabiting according to the number of childrenSource : INSEE, employment inquiry 1990 and 1998

Cohabitants are young people: almost 30 per cent of people aged between 25 and 30 are living in cohabitation. More women under 26 and men under 28 are living in cohabitation than in marriage. Nevertheless, cohabitation is no longer specific to the younger generations. A growing proportion of cohabiting couples are found among the elderly. As L. Toulemon (1996) argued, "cohabitation has become established".

The birth of a child is no longer a sufficient reason to get married. So we are also facing a strong increase of the number of children born out of wedlock: from around 6 per cent between 1945 and $1965 ; 6.8$ per cent in $1970 ; 11.4$ per cent in 1980 to 30 per cent in 1990,39 per cent in 1996 and 40 per cent at the end of the 1990s. In France, more than 50 per cent of first children are now 
born out of wedlock. This increase means that France is now third after Sweden and Denmark in terms of percentage of live births outside marriage.

But this increase is in a very different context from earlier times. During the "30 Glorieuses" (1945-1975), illegitimate children, as we called them at that time, were strongly stigmatized. They were considered to be prone to social maladjustment and delinquency because they had been abandoned by their father. Nowadays, most of the children are recognized by their father. In the 1970s one in five were so recognized at the time of their birth, one in two in 1980, and three in four in 1996. 85 per cent of children are now recognized by both parents after a year. Only 6 per cent of children are never recognized by their father and this proportion remains stable. Very often, cohabitation occurs between adults who already have children from an earlier relationship. Of the total number of unions between 1989 and 1993, with or without marriage, 16 per cent of men or women already had one child (Beaumel \& al, 1999).

If the decline of marriage and the increase of cohabitation are the main tendencies of recent decades, we could add also the postponement in the first formation of partnerships. After 1990, the proportion of young people living in cohabiting couples decreased at every age, because they form their first partnership later, and even sometimes in their parents' home. In 1999, only 30 per cent of 25 year-old men and 50 per cent women of the same age were living in couples, compared to more than 40 per cent of the men and 60 per cent of the women in 1990. This delay in the setting up partnerships may be a major transformation, linked to the social and economic conditions of young people, including a tendency to extend the time for studies, delay in access to a first job, the prevalence of unemployment in the younger generations and new intergenerational links between them and their parents. 
In sociological terms, probably the main distinction is no longer best made as being between juvenile and adult cohabitation but between two forms of cohabitation (Théry, 1998) :

- "provisional cohabitation" (cohabitation au présent) is a way of life associated with a new tolerance for sexual and affective relationship but without a long-term project of common life and/or family : this kind of cohabitation is widespread among young adults, but also among adults after a divorce or separation, or even after widowhood. Socially, this kind of cohabitation is not associated with a long term project, separation is not a very dramatic issue, and property is not considered common.

- "long-term cohabitation" is a way of living together associated with a long-term project, with or without children. In this type of cohabitation, the behaviour and values are no different from those in contemporary marriage: the partner is considered as an informal spouse, and cohabitation as a sort of "marriage without papers" (mariage sans papiers). The similarity between cohabitation and marriage is particularly evident as far as parenting is concerned: the rights and duties of parents and children are considered to be exactly the same. The modern distinction is no longer between "legitimate" and "illegitimate" children, but between children with two parents and the 6 per cent of children born to a real "lone mother ".

Of course, in spite of the fact that these different social significations are important, it is extremely difficult to distinguish between "provisional cohabitation" and "long-term cohabitation" in quantitative data (except when there are children). And, in fact, many of the long-term unions (married or not) begin as "provisional cohabitation". Sociologists underline that the new phenomenon is the tendency towards very "soft" and informal transitions in the life cycle (Roussel, 1989, Kaufman, 1996). Another problem is that it is difficult to know whether people in long-term cohabitation consider that marriage is definitely excluded for the future or not. One study reveals that in 1986 only 6 per cent of cohabitants categorically rejected the institution of marriage (Léridon and Gokalp, 1994). This could be one of the reasons for the recent increase in the number of late marriages . 
The problem of separation is linked to this ambiguity in the social significance of cohabitation. As in other countries, unmarried cohabitation in France is much more at risk of ending in separation than is marriage. But the significance of the separation differs according to whether the cohabitation is or is not provisional. Separation among young adults who have been cohabiting without children, for example, is not considered a dramatic phenomenon. Nevertheless, if we compare marriage with cohabitation with children, cohabitation is at far greater risk of break-up than marriage (Toulemon, 1996).

These developments show that cohabitation is now quite integrated in French society as a normal first stage in the establishment of a partnership, and even as a normal situation for millions of children. The situation of these children is very different from that of illegitimate children in past times, as almost three in four are recognized by their father when they were born, compared to the 6 per cent of illegitimate children at the end of the 1960s, who were also confronted with strong stigmatization and disapproval. This normalization process is leading to the total legal assimilation of legitimate and illegitimate children, and even the suppression of this old legal distinction, as has been suggested in two recent reports to the minister of Justice by Théry (1998) and DekeuwerDesfossez (1999). In that sense, cohabitation was not a major issue of public debate in France, not even in the field of family policy reforms, before the Pacs (Pacte civil de solidaritê) project was initiated. So, the nature of this project provided a means to avoid speaking exclusively about homosexual couples, and to bring together the interests of homosexual and heterosexual “modernist" couples.

\section{Homosexual cohabitation: towards social recognition}

Homosexual cohabitation: towards social recognition 
The distinction we suggested between provisional and long-term cohabitation may also be partially pertinent for homosexual relationships. Tolerance towards homosexual relationships has emerged roughly over the last decade. For example, in 1994, 75 per cent of a general population survey considered that "homosexuals are normal people" (les homosexuels sont des gens comme les autres) (69 per cent expressed that opinion in 1992). Nevertheless, a significant proportion of the population still sees homosexual relationships in terms solely of sexuality, refusing to acknowledge the long-term projects of these couples. Public opinion seems to find it difficult to accept that homosexuality may take the form of stabilized couples. The stigmatization still operates. Thus, a majority of young homosexuals (60 per cent of those between 16 and 20 years old) and a large minority of mature men (42 per cent of those between 36 and45) still conceal their homosexuality from their parents, mainly their father (Schiltz, 1997). Anonymity of the big conurbations is still important in the acceptance and revelation of homosexuality.

The main recent sources for assessing the number of homosexuals in France are linked to the AIDS epidemic. The major survey (on a sample of 20,000 people from 18 to 69 years old) is the ACSF (Analyse des comportements sexuels en France) financed by the ANRS (Agence nationale de recherche sur le Sida) in 1990 (Spira et al, 1993). This inquiry reveals that 4.1 per cent of men and 2.6 per cent of women who had a sexual experience, had at least one same-sex partner. These largely occur in urban areas: 5.9 per cent of men and 4.1 per cent of women living in the Paris conurbation declared such a practice compared to only 1.6 per cent of men and 1.2 per cent of women living in the countryside. The maximum proportion was found among 50-54 year-old men in the Paris conurbation (more than 11 per cent). Almost 50 per cent of these people mentioned that they had also had sexual relationships with people of the other sex, which means that homosexuality is often bisexuality, which poses a major problem for the prevention of AIDS. These data, which concern only sexual behaviours, could have indirectly reinforced the perception 
that homosexuality is mainly a sexual orientation, without concern for a long-term future as couples. Nevertheless, an inquiry undertaken each year from 1985 through the homosexual press shows other aspects of homosexuality (Schiltz, 1997). 90 per cent of the 2,600 men who in 1995 answered a questionnaire distributed in ten homosexual magazines defined themselves as homosexuals, and even as exclusive homosexuals. Six in ten declared that they were living in a stable relationship, which does not necessary mean an exclusive sexual relationship, nor even a cohabitation. Nevertheless, the effects of the AIDS epidemic led these people to be more sexually exclusive. But it is important to underline that 32 per cent of the respondents were cohabitants in an exclusive sexual and emotional relationship. Around 25 per cent were having apart-together relationships. Most co-residence was by people in their thirties. The increase of co-residency, which in a way makes homosexual couples nearer to heterosexuals, and the relative decline of multi-partnership, should not obscure the specificity of homosexual couples, which is still very close to a single way of life. For a homosexual, to be engaged in a stable relationship does not necessarily mean co-residence or fidelity. But despite these specificities, homosexuals increasingly demanded social recognition of their partnerships and legal protection. The debate about Pacs was a result of that mobilization. The debate was clearly initiated by homosexual movements in order to obtain recognition of homosexual couples in the context of the AIDS epidemic. In particular, the associations close to the socialist party (Les gais pour les libertés, Homosexualité et socialisme, for example) succeeded in setting this issue on the political agenda. Initially, Pacs emerged as a proposition to respond to the dramatic situation of homosexuals who were evicted from their homes after the death of a partner, or deprived of the fruits of a common enterprise, because of the total absence of legal protection

-This mobilization has in a way helped to construct an artificial "homosexual community", or a sort of model of identity, around the common difficulties of homosexuals. Nevertheless, this debate triggered off a deep questioning on the frontiers of the family. To recognize the right of homosexuals to live in partnerships and to obtain legal advantages equivalent to those of 
"legitimate" couples, and to break with discriminatory attitudes and homophobia leads ineluctably to the acceptance of homosexuality as a legitimate way of life and even as a form of family life.

The chronology of the events around the Pacs shows the importance of lobbying and the progressive setting of homosexual issues on the political agenda (Commaille \& Martin, 2000). This lobbying began to appear more clearly when a very few socialist politicians announced publicly their homosexuality (coming-out). ${ }^{\text {iv }}$ The homosexual movement was increasingly structured and visible, from the grass-roots level, with important resources of mobilization (such as the enormous success of the Lesbian and Gay pride, particularly in 1996), to the top levels of influence with experts, politicians, journalists, etc. In this process, family associations - the traditional, legitimized and official partners of the State and Parliament on family issues - were marginalized. ${ }^{\mathrm{v}}$

The debate vacillated between many issues: recognition of homosexuality, which is not necessarily connected with family matters; recognition of homosexual couples' rights (frequently in terms of comparison with married and non-married heterosexual couples); recognition of the households where children are living with one of their parents and a same-sex partner as a family ("homoparentality"); and, finally, recognition of the possibility for a homosexual couple to adopt or even to have a child with assisted reproduction. Some issues mainly concern recognition of the individual, while others concern the recognition of couples; and others concern issues of filiation. On these various issues, family associations defended a traditional position, mainly in its Catholic form (Commaille \& Martin, 1999).

We suggest that we might speak of a change in "citizenship regime" (Jenson, 1997), in the sense that the legitimized actors who define social norms and rules, and categories which might give rise to rights, are changing. In a way, the debate on the Pacs contributed to a visible and explicit decline of the legitimacy of the family associations as representatives of the family interests. Their positions appear to be too traditional and conservative to be acceptable to public opinion. With the 
debate on the Pacs, a new and increasingly recognized interest group appeared, the "homosexual community", albeit that that hypothetical community is much more fragmented than it is generally represented to be (in terms of gender, generations and social stratification, with important consequences in terms of lifestyle and mobilization).

\section{Marriage and cohabitation: the legal context before the Pacs}

The growth of cohabitation in France has been, sociologically, a soft revolution. Nevertheless, this quiet change does not signify that in France people unequivocally accept the historical phenomenon of “démariage " (Théry, 1993). Ambiguity appears on any occasion when legal issues or policy issues are concerned. It appears difficult for French culture to think of marriage and cohabitation together: the one is constantly contrasted with the other. A certain social anxiety appears in this incoherence of social expression. French legislation is far from giving cohabiting couples the same social and fiscal rights as the married. The complexity of cohabitation's social signification must be remembered when considering legal evolution before Pacs. French legal attitudes to cohabitation are very mixed.

\section{A-Cohabitants as a couple: persistence of the Napoleonic attitude}

Except in very particular circumstances, in civil law cohabitants are considered as independent persons, and not as a couple. In a way, the old Napoleonic attitude of 1804 is maintained: “ They don't want law, law pays no regard to them ". Consequently the civil law makes no provision in case of their separation or death. Cohabitants are treated as if they were strangers to each other. In case of illness, a cohabiting partner has no right to be consulted over medical decisions. In case of death, the partner has no right to make decisions about the funeral. And, of course, there are no inheritance rights. Nor can a cohabiting couple adopt a child together. In the recent past, jurists had a long debate over creating a " status " for cohabitants, but this failed (Rubellin-Devichi, 1986; Meulders, 1999). So, "in the shadow of the law", the courts have developed a jurisprudence based on "société de fait" or "enrichissement sans cause" 
where separation causes damage, a very indirect and limited way of solving problems (Hauser et HuetWeiller, 1989; Carbonnier, 1999).

The attitude of the Civil Code towards cohabitation is followed in fiscal law. Cohabitants are not considered as a couple for the purposes of the annual income tax; only married couples can declare their income jointly, which is in most cases advantageous for them (this difference between the married and non-married was accentuated in 1995 when cohabiting parents lost the fiscal advantage they had previously enjoyed, as lone parents, regarding children). As far as succession rights are concerned, the free voluntary legacy which might be made to the cohabiting partner is severely limited by the "reserve" for children and ascendants. The taxation applicable to these so called "strangers" is 60 per cent for amounts above 10,000 francs. On the other hand, social law is based on concrete situations, and tends to recognize "concubinage", but mostly in a negative way. Holding "de facto solidarity" between the partners to be an advantage compared to living alone, social law increasingly refuses to treat all "non married"persons equally. So, entering cohabitation will lead to the loss of some allowances which are targeted at lone persons, especially lone parents: the allowance for lone parents (API), the allowance for family support (ASF), and the allowance for widowhood (pension de reversion). It will reduce others, like minimum income benefit (RMI) or housing allowances. Compared to benefits conferred on cohabitants by many insurance companies, and by public and private transportation companies (SNCF, Air France), French social law is very parsimonious. The only social rights derived from cohabitation are to remain in the common rented home after a separation or death, and to be considered as a social security beneficiary of the partner where there is no income. But this last benefit disappeared in 1998 with a new law on "Couverture maladie universelle" which gives to everybody a right to " social security". So, for civil and fiscal law, only a married couple is considered to be a real couple, while for social law, cohabitation is recognized, but usually in order to remove or diminish allowances for single people.

This legal situation arises from almost contradictory factors. One the one hand, there is a strong 
traditional "marital preference" in French culture holding that people who are not legally linked together should not benefit from the State in the same way as people who have proved their mutual commitment. This attitude is widespread among the traditionalist part of the population who see the change in the family as a threat to society due to growth of "individualism" (Sullerot, 1984). On the other hand, the new lifestyles have a strong influence. We can notice that until recently, most of long-term cohabitants seemed to accept the lack of legal protection as a consequence of the individual freedom of their relationships. For example, there is no claim between separating cohabitants for some "prestation compensatoire" which, in a divorce, can be paid to the spouse whose financial situation is damaged by the ending of the marriage in spite of the fact that, among cohabiting couples, the traditional gendered division of tasks continues. Similarly, it seemed accepted that if you want to make provision for the survivor after death of a partner, there were new private solutions: contracts, life insurance and so on. This is now beginning to change, since a significant proportion of French cohabitants are now in their fifties. The homosexual movement also illuminated the legal problems many heterosexual people faced in private life.

\section{B Cohabitation and parenthood: a soft revolution}

The position of heterosexual cohabitants who are parents is entirely different. There is almost complete assimilation of rights and duties for children, independently of the legal situation of their parents.

\section{a) the great reforms of the $1970 \mathrm{~s}$}

In 1972, the reform of filiation introduced a very important legal change. It allowed the natural child to inherit. This was considered as the legal acknowledgment of another form of family, alongside the family based on marriage: the "natural family". More than that, the principle of equality between legitimate and non legitimate filiation was guaranteed by a new article in the civil code (art $334 \mathrm{cc}$ ).This was, after centuries where the "family" was based exclusively on marriage, a revolution in the civil law (Carbonnier, 1979). Traditional jurists and conservative politicians considered this to be a decisive attack on marriage. In fact, this reform was a legal compromise. Marriage as an institution had to be protected. 
So, children born from adultery only receive half of the inheritance they would have had if there were legitimate.vi During the same period, two important reforms indicated that marriage was considered the “normal” way of family living:

-in case of non-marriage, no distinction is drawn in establishing filiation between cohabiting and noncohabiting parents: the parents, especially the father must recognize the child. But the reform on parental authority (1970) established that the exercise of parental authority (exercice de l'autorité parentale)will be attributed only to the mother since this was considered to be "social reality". If the father wanted to exercise parental authority, he needed to resort to a judicial procedure.

-in case of divorce, the reform of 1975 (introducing divorce by mutual consent) removed the link between fault and the attribution of custody. In all cases, custody had to be attributed to "one or the other parent" according to the best interests of the child. This indicates that outside of marriage, namely outside a legal couple, French law considered that the child cannot have two parents with equal rights, exercising day to day responsibilities. To summarize the legal situation at the end of the 1970s, apart from the important reform of filiation, marriage remained pre-eminent. We must remember that, at that time, nobody anticipated the rise of non-married parenthood nor the increase in divorce. The Minister of Justice (Jean Lecanuet) explained in Parliament in 1975 that "marriage has never been as healthy as it is now", and that “ modernization of divorce will strongly reinforce marriage "(Théry, 1993). Legal change was not seen as a revolution. For society, it was no more than a way of being "human" towards the rare situations of children born outside marriage, and a part of the modernization of the country engaged by the liberal right wing government (The Presidents were successively G. Pompidou, V. Giscard d'Estaing).

\section{b) The growing equality of parenthood}

But family change rapidly proved to be very important, and in the 1970s and 1980s the recent reform of civil code became an unexpected factor of social cohesion. When increasing numbers of non-married couples decided to have children, they knew that these children would not be social and legal outcasts. This is certainly one of the major reasons why the French "revolution of marriage and cohabitation" was a 
soft one. Nevertheless, two problems emerged in the social and political agenda: that of fathers' rights and their involvement in non-married and in broken families. These questions must also be seen as being as much a problem for women (who had most of the personal and financial burden of educating the children in a lone parent family, when the father does not assume his responsibilities), as a problem for men, when they protest against their " eviction" by the mother after a separation or a divorce.

During the 1980s and 1990s claims for equal rights and responsibilities for fathers and mothers, and for all the parents whatever their situation increased. The same socio-cultural movement occurred as in other countries, the emergence of a strong response to "démariage " in the affirmation of the double filiation as a family link founded on the principle of indissolubility of parenthood (Théry, 1998). The International Convention on Children's Rights (1989) expresses this principle in Article 7.1 which states the rights of children "to know and be cared for by his or her parents". But, in France, this principle turned out to be much more complex than it seems, and is not yet achieved. The main legal reform was the introduction in 1987 in the civil code of the possibility of acquiring joint parental authority, and in 1993 the affirmation of joint parental authority as the principle for all parents (Carbonnier, 1999). But these reforms also revealed the traditional French ambiguity. One the one hand, the law proclaimed equality (between married and unmarried parents, between fathers and mothers) but on the other hand expressed a real reluctance to give up the traditional preference for marriage, for (1) although after 1993 the unmarried father is entitled to exercise parental authority, this is only if the parents can prove they were living together at the moment of the legal recognition. (We can see here how difficult it is for French people to think of "two parents" without seeing them as a couple); and (2) although divorced or separated parents have joint parental authority as a matter of principle, in 1987 and 1993, joint physical custody was strongly opposed on the ground of the child's psychological well-being (The very influential psychoanalyst, Françoise Dolto, played a great role in that debate, condemning parents who "share their children as objects"). The legal obligation of designating the children's "principal home" reintroduced the perception that, without the family unit, or the household unit, or the unity of a couple, it is impossible for 
children to have two "real" parents.

One of the consequences of this debate is that many judges are reluctant to award joint physical custody, although parents increasingly choose this solution. Many divorced parents who share physical custody declare they are obliged to conceal this from the judge (Neyrand, 1996). Another consequence is that judges are extremely reluctant to order joint physical custody if one parent disagrees. However, the attitude of the courts is changing; growing numbers of divorced fathers see their children weekly (20 per cent in 1994), and for a longer period (often from Friday evening to Monday morning). Nevertheless, changes in parents' attitudes must not be overestimated: in 1994, 25 per cent of divorced fathers had lost contact with their children (Villeneuve-Gokalp, 1999). Fathers' involvement in the children's lives is significantly lower among the less educated part of the population (Martin, 1997; Villeneuve-Gokalp, 1999).

To summarize, the legal situation just before Pacs debate began in France was highly complex: unmarried parenthood was almost assimilated to married parenthood, in spite of some "residual" differences, specially for children born in adultery. As far as parenthood is concerned, the main issues were no longer between marriage or cohabitation, but over the problem of separated or divorced parents. At the same time there was a growing movement towards a dual responsibility, and the use of new criterion (résidence principale) accentuating the need to choose between mother and father. The legal situation of cohabitants as couples remained unchanged as far as civil law was concerned: they were considered as "strangers". Social and fiscal law was very problematic and contradictory.

\section{The Pacs : the complexity of the legal "French way"}

On 15 November 1999, Pacs was promulgated (loi sur le concubinage et le pacte civil de solidaritê), after a passionate debate in the National Assembly and the media. In contrast with a growing discussion 
about homosexuality, one can observe that the most important legal changes in the project from its first presentation (June 1998) to the final vote (October 1999) occurred without debate or even the opportunity for anyone but a handful of specialists to understand it. As a young student said, in February 1999, during a seminar devoted to the project : "Everybody is for or against the Pacs, but nobody knows what it is ". To understand the "French way" of giving rights to same-sex couples, and finally the main characteristics of Pacs itself, it is necessary to revert to the beginning of the legal story .

\section{A. Before the Pacs : 1989-1997}

As we said above, during the 1980s, in the context of AIDS, homosexual couples experienced many legal problems. The Cour de Cassation refused in 1989 to consider same- sex couples as cohabitants (concubins), and decided that cohabitation must be strictly defined as "marital life", that is, heterosexual (this was confirmed by another decision in December 1997). Even the limited social rights of heterosexual cohabitants were therefore denied to homosexuals. A small group in the homosexual movement then initiated a long campaign for the "legal recognition of the same sex couple".

On the basis of proposals by some homosexual activists, four projects were successively put forward by the leftist parties:

- partenariat civil (Senate, 1990)

- contrat d'union civile (National Assembly, 1992)

- contrat d'union sociale (National Assembly, 1997)

- contrat d'union civile et sociale (French National Assembly, 1997).

A legal analysis of these successive projects reveals a real diversity of conceptions among the homosexual activists and among the left wing (for a detailed analysis of the projects and the debate, see Théry 1997). The first project - partenariat civil- is the "lightest": a contract between two persons, registered by the mayor, but ending without any formality should one partner decide to break his commitment (a registered letter would be sufficient to end the contract). In contrast to this "light" commitment, the various marital property regimes would apply and the partner would inherit like a 
spouse, with the same taxes. The three other projects were much more elaborate. Their main common characteristic was a strong similarity to marriage, but with two important differences :

- divorce would not be necessary to break the contract. Separation would be an administrative act, instituted by only one party. In case of conflict the judge would only deal with property.

- the contracts would have no consequences for filiation and give no rights for adoption or artificial insemination.

Nevertheless, as far as couple-relationship is concerned, the projects can be defined as "quasimarriage" (Théry 1997): exclusivity of all other unions (marriage or another civil contract), registration by the mayor, change in civil status (implying support and assistance), the same regimes for property as in marriage, guarantee to the surviving partner of a right to inherit like a spouse, and also all the social and fiscal rights married people have. But the successive projects differ on one point: the people to whom they would be available. This has all along been the major point of divergence between the activists promoting a new legal status. Some consider that the contract must be open to every kind of "pair" (couples, friends, brothers and sisters etc ). This is the case in partenariat civil, the contrat d'union civile and the contrat d'union civile et sociale, which came from the same part of the movement. On the other hand, some activists consider that the major issue is to achieve legal recognition of same-sex couples as legal couples : the contrat d'union sociale, like in the Dutch legislation would have been open only to couples, heterosexual or homosexual. In this project, incest is clearly excluded: prohibitions are the same as in marriage. But we must notice that the major part of the homosexual movement seems not to have distinguished between these two legal perspectives; during the 1990s, the claim for a "contrat d'union sociale" grew, but this was a general goal. Legal discussion was confined to a very small circle of activists.

1997-1998: the moment of decision 
In 1997, the leftist parties were successful in the legislative elections. The programme of the socialist party included the commitment to legislate for the "contrat d'union sociale". Pressure from the homosexual movement was strong and the project was considered a priority. But ambiguity grew: was the contract intended to legalize solidarity between two persons or to create a new legal union for couples? Was it a "light" contract or a quasi-marriage? The politicians gave no answer, other than to insist that the project was not confined only to homosexuals. But legal choices could not be avoided. In fact, the previous projects were abandoned and two MPs (J-P. Michel et P. Bloche) were charged by the Commission des Lois of the National Assembly to elaborate a new one. The reason was that a " quasi marriage " for all persons (even brothers and sisters) seemed absurd, but a project obviously devoted to homosexual couples could be divisive. Most leftist MPs feared they would not be reelected if they supported homosexuality.

Three projects appeared in succession, the first two in official government reports. In February 1998, the " pacte d'intérêt commun (PIC) " was presented by Professor J. Hauser. It is only a private contract dealing with property, concluded in a solicitor's office, available to everyone, even married people. The PIC nevertheless confers substantial income tax benefits and social rights. The media saw this as the new solution. At the beginning of May 1998, Irène Théry delivered to the government a report on family change and the civil law, Couple, filiation et parenté aujourd'hui (Théry, 1998). In a section devoted to cohabitation (concubinage), it proposed that a specific article should be added to the civil code, treating "concubinage" as cohabitation by a couple of the same sex or of different sexes. Cohabitation lasting at least two years woud be afforded the same social and fiscal rights as in marriage.vii At the end of May 1998, Pacs was presented to the media by P. Bloche, J-P. Michel and C. Tasca, the President of the Assembly Commission for Law. The new project was a "quasi marriage", available to heterosexual or homosexual couples. As in the previous projects, filiation and adoption were not included, and divorce was not necessary in case of separation. Property was to be organized in the same way as the "régime primaire" in marriage ("communauté réduite aux acquêts") and the partner was to 
be considered as legal heir. We must also notice that, even though no-one tried to amend the legal project accordingly, during 1997-98 some sections of the homosexual movement began to advance a new claim: the right to marry and adopt children. This was considered by its advocates as bringing about " perfect equality" between homosexuals and heterosexuals (Borillo, 1998).

What choices did the French government make? The first choice was not to be directly implicated: the project would be the exclusive responsibility of Parliament. The second was to opt for the Pacs but, at the same time, to transform it radically. The Prime Minister, Lionel Jospin, did not wish the Pacs to be another form of marriage. It must not even be compared to marriage. During the summer 1998, important modifications of the project were imposed :

1. Pacs would not be concluded before the mayor, but in the "tribunal d'instance", a place of much less symbolical significance; the property regime was changed to one of co-ownership; the partner of a Pacs was no longer to be treated as legal heir; the obligation of "support and assistance" was removed; taxation in case of succession was to be much more onerous than for a spouse; the right to joint taxation would arise only after three years.

2. In spite of prohibition for close relatives, it was not clear if Pacs was to be for couples only or for any kind of pairs of non-relatives (friends, colleagues, churchmen etc..).

3 It was not clear if Pacs would be a union or a simple contract for property: the only obligation would be for "solidarité mutuelle et matérielle".

A strong indication of the ambiguity of the "new" Pacs, transformed by a summer of negotiations, was that Théry's proposal of an article in the civil code about "concubinage" was turned 
down. To introduce the expression "same-sex couple" into the French Civil Code was considered "shocking" for public opinion. This assumed that the jurisprudence of the Cour de Cassation would be maintained. This legal ambiguity showed the political anxiety of the socialist party about same-sex partnerships. In fact, at the beginning of the autumn, most of socialists MP were hesitating, and some were not convinced at all by the project itself. The consequence was that when the project was presented for the first time at the National Assembly on 9 October 1999, most of socialist MP were not present, and the project was rejected.

\section{B. The three paradoxes of Pacs}

After this unexpected political defeat, a very heated debate took place in the National Assembly and in the media. The left decided to present immediately another Pacs, which the media dubbed "Pacs II ". The main consequence of the first defeat was a radicalization. The left perceived that the political benefits were greater than the risks, and finally took up the defence of homosexual couples. On the right, the more conservative MPs defended " family values " against the "social decline" they considered symbolized by the Pacs. But paradoxically there were many divisions and debates in each camp, although they remained hidden. This appears more clearly if we look at legal issues.

Pacs II was to be open to brothers and sisters, so as to avoid a clear legal recognition of samesex couples. During the autumn, leftist MPs became increasingly divided over same-sex cohabitation. Some were convinced that it was necessary to introduce a specific article into the law, but others (for example E. Guigou, Minister of Justice) refused this categorically. The argument was that legal recognition of same sex-couples would "open the door to homosexual filiation" (Gélard, 1999, p. 298). The other growing division is about brothers and sisters: some wanted to exclude them and assumed the Pacs was a new form of legal union for couples, and others rejected this. The right was no less divided. Many did not agree with the so-called traditional family " fundamentalists ", such as the MP Christine Boutin, the leader of the "Pacs out" campaign. The Senate rejected the project and in March 1999 the Commission des 
Lois of the Senate produced an alternative. Its purpose was to extend some fiscal advantages to cohabitants (but inferior to those enjoyed by married people), but the project declined to add an article on "concubinage" in the civil code which would refer explicitly to same-sex couples (Gélard, 1999).

Finally, this legal battle, incomprehensible to almost all the French people, ended with a vote by the National Assembly in November 1999. The final text integrated some amendments. Pacs for brothers and sisters was rejected, and the article on "concubinage" naming same-sex couples was introduced into the civil code, changing the title of the law (which becomes : "Law on concubinage and Pacs"). In spite of these clarifications, the complex legal story explains that the law voted by the National Assembly on 15 November 1999 remains largely uncertain. Pacs is neither a legal union nor a simple property contract. It is neither public nor private. It is neither for couples nor for pairs of friends. It is neither a legal recognition of same-sex couples nor is it non-recognition (Murat, 2000). The choice seems to have been a kind of “neither-nor"politics.

[In summary, Pacs is available only to two persons of the same or the opposite sex, but excluding persons who are related to each other, or who are in an existing marriage or Pacs; it is entered by registration of the contract at a tribunal d'instance, but the tribunal does not scrutinize its contents. The Pacs is immediately terminated if either party marries, but otherwise may be terminated immediately by agreement, or three months after unilateral repudiation communicated to an official. Property relations will be determined by the contract, but in default co-ownership will apply. They are treated as partners for social security purposes, as any other "concubins". There are no succession rights except to tenancies, though after two years there is some tax advantage for gifts made on death, and after three years their income is taxed as if they were married. Distribution on property after termination is fixed by the parties, or, in default, by a court]. 
Three paradoxes of the law can be underlined (Théry, 1999) :

1. Pacs was not, in spite of the discourses and the heated debates, legal recognition for homosexuals as legal couples. This was only obtained by the article on "concubinage" which was finally added to the law. It was only after the final vote that Constitutional council (Conseil constitutionnel) gave an official interpretation of the law and decided that only two persons cohabiting as a couple can conclude a Pacs. 2. The second paradox of the Pacs is the unexpected subordination of the "free union" ("union libre") and of cohabitation that it implies. During the parliamentary debate, it was repeatedly declared that those who have no commitment to one another should not expect the State to give them social or fiscal rights ("No rights for those who have no duties"). In a way, whereas the law was proclaimed resolving the problems of people "who don't want to marry or cannot marry", as far as social and fiscal law is concerned, Pacs seems to be a return to Napoleonic attitude on cohabitation. There are now in France three types of couples: the married, the " pacsed ", and cohabitants, with a hierarchy of taxation in fiscal law. People who live together for twenty years can still remain " strangers" for the purposes of income or inheritance tax.

3. The third paradox is that the right of same-sex couples to conclude a real legal union (by a registered partnership or marriage) was not discussed in the Assembly. The principle of "republican equality", which was proclaimed as the specific French way to avoid "communautarist" legislation for same-sex couples, has led to a much more unequal law than in other countries. Homosexuals who want to conclude a legal union will not have in France the equal rights and dignity they have, through registered partnerships, in other European countries like Denmark or Sweden. Marriage, now possible for same-sex couples in the Netherlands, has not been considered a serious legal issue by French politicians, in spite of the efforts of some very active leaders of the homosexual movement.

In conclusion, Pacs seems a transitory legislation. There were 6,200 pacs concluded by the 
end of December 1999, over a period of one month and a half. It is interesting to notice that sociological statistics have been forbidden by the "decrets d'application" of the new law. Age, profession, even the sex of the partners must not be communicated by the "tribunal d'instance". Many sociologists and demographers protested, and this will certainly change in the near future, but it is a sign of the anxiety and uncertainty of the socialist party about this legislation. In spite of the lack of sociological research, some journalistic inquiries give an idea of the first Pacs concluded. ${ }^{\text {viii }}$ The " neither-nor " politics, that we have described throughout the legal project, seems to have created a " neither-nor " social and legal statute. By signing a Pacs, one party can consider himself or herself as "almost married " and the other as "almost in a free union". For some couples, specifically among homosexuals, to conclude a Pacs is often an occasion for a ceremony and a feast very like a marriage, despite the fact that the "tribunal d'instance" is very different from the Town Council in French republican symbolism, and in spite of the very few rights and obligations contained in the law. One can see, here, a hope and an expectation for some institution which is much more official, symbolically and legally much more important, than a simple Pacs. For other couples, on the other hand, Pacs is concluded very briefly, without any ceremony, as a bureaucratic obligation to obtain advantages in employment or income tax advantages. One can see, here, an expectation for a real recognition of the free union, and equal social and fiscal rights for concubins" living together for some years.

But most of the problems, from a legal point of view, are just beginning to appear. French jurists and lawyers are now examining the legal consequences of the Pacs. Most of them agree that the breaking of a Pacs will create many problems regarding division of property because of the "co-owner regime" (Murat, 2000). Nobody knows what will happen to property if the partners decide to marry one another. Another problematic issue is that the Pacs conventions are private, which means that they are not verified by any authority, not even a lawyer. Many conventions will turn out to be illegal. For example, many people believe that a Pacs is a means for bequeathing money or property to the other, but it is not. They might then illegally include some dispositions for inheritance in their convention, causing serious 
problems for the future survivor. All these examples show the uncertainty of the Pacs law. There will certainly be some legal change in the next few years. The history of the French Pacs is only beginning.

\section{Conclusion: From Marriage and cohabitation to sociological interpretations of the}

\section{family changes}

The contrast between the importance of social change in behaviours and values and the uncertainty of the legal provisions we have analysed in relation to the contemporary French perception of "couples" is an indicator of a larger question. There is not yet in France a consensus about the changes in family and private life in general. A look to the academic debate is important, insofar as public debate is increasingly affected by the arguments and ideas of the experts, whose advice is frequently sought by politicians, in particular through the production of official reports. This phenomenon is so important that many analysts consider France as a "Republic of reports".

Two topics have dominated most of the French academic debates about family change during the past twenty years more than marriage and cohabitation: divorce and fertility. Fertility is a typically French political problem, originating in the long history of wars since the nineteenth century and accentuated specially by World War I. We must emphasize that most of French family policy has been natalist for many years. There has sometimes been a very strong debate among demographers, between those who consider the fertility rate as the major indicator of a " civilization crisis " and those who contest the use of this indicator, compared to the achieved birth rate (Le Bras, 1991). This theme reveals a real "struggle over the meaning of statistics". But recently, this debate seemed to be radically reoriented, when it began to be recognized that fertility is highly connected with women's access to the labour market. The longstanding link between the demographical preoccupation and a very traditional view of the family (woman as an housekeeper, three or more children) has been disrupted. Certainly this field of research and debate will be largely reorganized in the future, with growing attention being paid to the birth of the first baby, the life cycle, and a gendered approach to the relationship between family and work. 
Divorce has been another important topic of debate among researchers. In a way, all the French debate about marriage was expressed, until recently, through divorce. During the 1980s, the focus on custody as a problem of inequality between fathers and mothers and the fact that a large number of groups for divorced fathers were established, explain why the issue of the lack of the exercise of responsibility by fathers (especially in the poorest sections of the population) has been largely underestimated. This debate has been associated with a largely psychological approach of "how to avoid conflicts“ (Théry, 1993; Bastard et alii, 1996). Very little social research looked at social inequality in divorce or separation. Even if there are in France recurrent attacks from traditionalists in the conservative parties against "one parent families", lone motherhood is not a political and academic issue in France as it is in Great Britain and the USA (Martin, 1998).

From the mid-1960s to the beginning of the 1980s, public opinion usually saw the transformation of the family as a crisis and a threat. This consisted in a caricature which opposed the "20 Glorieuses" or the Golden Age of the family (1945-1965) and the "30 piteuses", thirty pitiful years for the family (19651995). Indeed, if we want to understand the current transformation by a comparison with the traditional family of an hypothetical golden age corresponding to the 1945-65 period, the diagnosis seems simple: it compares the stable nuclear family (founded on marriage and institutions, very fecund, with strong ties and obligations, etc.) to a fragile family, with weak links and solidarities (Sullerot, 1997). That nostalgic position ignores that this strength of the traditional family was founded on a strict and unequal division of the gender roles and on the dependence of the female within the marriage contract. It ignores also that this period was exceptional in the long term history of French family. So, many aspects of recent family changes appear to have been extraordinarily dramatized and even falsified by a myopic approach, concentrated on the second part of the twentieth century.ix (Théry, 1998). 
In the long term, French debate has been mainly organized through the opposition between family and individual. This is probably a consequence of a very long history, beginning with the French Revolution. The creation of civil marriage in 1792 was the symbol of a secularized society and equality of citizens before the law. Civil marriage was at the same time the symbol of the link between republican political ideals and the private sphere. From 1789 to 1793, a short but historically very important period, all the problems regarding the family were reconstructed as a problem of individual liberty and equality. The family was seen as a private sphere and revolutionary laws were introduced (the divorce introduced in 1792 was more liberal than French divorce today).

But rapidly after the period of " Terror ", another interpretation of "family" emerged. Family was considered as a condition for assuring social order and as the natural bedrock of society. The Napoleonic code of 1804 promoted one unique model of family as "the" family for more than a century and a half. Marital and paternal power organized the family as a very hierarchical unit. Only the married family was considered to be a family. Liberal revolutionary divorce was limited, and finally suspended in 1816 for almost one century (when divorce was reintroduced in 1884 it was only a fault-divorce, until the reform of 1975).

This history explains the long lasting opposition between conservative parties, strongly influenced by Catholicism, and progressive or socialist parties, contesting this family model in reference to individual liberty, secularism, and equality. This opposition is so strong in French culture and public debate, that the word "family" seemed, until very recently to belong to the right wing. Until the 1990s, it was most unusual for the left wing to refer to the family as a value at all.

This dichotomy led to the identification of the "family" with the traditional family. So it is not surprising that the recent change in family behaviour and values was interpreted among academic commentators as " the passage from family to individual " and a movement towards " privatization "of norms. Demography and family sociology has expanded a great deal since the 1970s, but most of the researches were 
devoted to specific aspects, telling very little about family change in general. The reason is that a sort of explanation was largely accepted: we faced "new behaviours", "new values", "pluralization" of the family forms. Depending of each political choice, this was seen as a symptom of decline, decadence, individualism, egotism (among jurists and some demographers), or, on the contrary, a cultural emancipation, more freedom and social tolerance (among sociologists). But the main expression was “from family to families" (see Revue française des affaires sociales, 1983).

The 1990s changed the issues and the hypothesis of a "passage from family to individual" was contested. This aspect became more important after 1995, when social problems and specifically teenage delinquency were attributed to a lack in family education, generating a strong political debate. So, beyond the ideological position which understands the present tendencies of transformation of the family as a destruction, a threat, a peril, and which considers that the best solution to be to go backwards, "back to basics", we can identify different more theoretical positions which show the difficulty in understanding the present and the future.

The meaning of these transformations of the family may be synthesized in four main positions, often interconnected (see Déchaux, 1995; Commaille and Martin, 1998 and Théry, 2000) :

-first, we could group together the positions of researchers who consider that the main transformation of family life corresponds to a process of emancipation from tradition (Beck, 1992), a progressive recognition of the individual within the family, and mainly a process of emancipation of women. This interpretation considers that this is mainly positive and gives the family a new structure, more horizontal and more equal, more contractual (famille élective) more centred on the production of identities than around transmission of goods (de Singly, 1993 and 1995). By analogy, it could also correspond to a new public order, not the vertical conception of social order founded on a structure of delegation of power from the top (God) to the bottom (the father), but a democratic order founded on mutual recognition (Giddens, 1992). 
-But, this first position is immediately counterbalanced by the reminder of the limits of the individualization process in terms of the threat of " de-institutionalization" (Roussel, 1989). How can we preserve the common good, the collective foundations of a society, without symbolic signs and collective norms? How may we even form a society if the only links we recognize are defined on the basis of the interaction between individuals ? Such a position may insist on the role of law, as a symbolic link which gives meaning and consistency to the social relations inside family: horizontal (couple) or vertical (filiation). These limits to the "de-institutionalization" of the family are very close to those identified by Alexis de Tocqueville in the nineteenth century or Durkheim at the beginning of the twentieth in terms of the risk of individualism.

-A third position in these debates considers that a second risk and brake to this positive progress of individualization is constituted by inequalities: inequalities between social groups and classes and inequalities between genders. The process of emancipation is not equally accessible and the main proof of this inequality is, for example, the unequal consequences of separation and divorce, depending on the social and economic conditions of the families (Martin, 1997 and 1999, Commaille 1999). On the other hand, traditional norms still represent a reference for many social groups. Individuals in these configurations do not recognize themselves in the new gender or intergenerational roles. In these cases, separations, divorces, births outside marriage, etc, are still considered as pathologies and sources of social problems. In this perspective, the process of individualization may accompany a regulation of the social inequalities and problems linked to these transformations of family.

-Another position rejects the sociological hypothesis of individualism (as well positive or negative) and introduces a gender and age approach of family change (Théry, 2000). This hypothesis argues that growing equality between men and women is the most important factor of change, and has been largely underestimated in France for years. The general thesis is that the "matrimonial model" of the family, presuming a gender share of public and private in fact implodes in the 1970s. It is an anthropological revolution we are just beginning to be conscious of, and is largely incomplete. Fertility, nuptiality, and divorce must be reconsidered in this perspective. The other major factor is the change in ages and intergenerational relationships in a context of a rising life expectancy (Attias-Donfut \& Segalen, 1998). The entire life cycle is reconstructed. In this perspective, family change is a structural mutation, generating new 
forms of social inequalities and requiring the elaboration of new institutions, and a complete change in family policy defining a " new gender contract " and a new " generational pact ".

These different positions represent a very simplified scheme in which it is possible to place the arguments about family change and family reforms. We can easily consider that the arguments, the ideas, the social references are swinging in the political debate between these different interpretations of changes, according to circumstances and mobilization.

\section{Bibliographie :}

Attias-Donfut C., Segalen M. (1998), Grands-parents. La famille à travers les générations. Paris, Odile Jacob.

Bajos N., Bozon M., Ferrand A., Giami A., Spira A. (1998): La sexualité au temps du Sida. Paris. PUF.

Bastard B., Cardia-Vonèche L., Eme B., Neyrand G. (1996), Reconstruire les liens familiaux. Nouvelles pratiques sociales. Paris, Syros.

Beaumel C., Kerjosse R., Toulemon L. : «Des mariages, des couples et des enfants » Insee Premières, n? 24, janvier.

Beck U. (1992) : Risk society. Towards a new modernity. London, Sage.

Borillo D. (1998) : “Le mariage, un droit fondamental”, Ex-Aequo, février, p.40.

Carbonnier J. (1979) : Essais sur les lois, Paris, Répertoire du notariat Defresnois.

Carbonnier, J. (1999) : Droit civil, II. La famille, Paris, Presses Universitaires de France, coll; Thémis.

Commaille (dir) (1999), Famille et chômage. Rapport pour le Haut conseil de la population et de la famille. Ministère de l'emploi et de la solidarité.

Commaille J, Martin C. (1998), Les enjeux politiques de la famille, Paris, Bayard.

Commaille J, Martin C. (1999), «Les conditions d'une démocratisation de la vie privée », in D. Borrillo, E. Fassin \& M. Iacub (Eds), Au-delà du PACS. L'expertise familiale à l'épreuve de l'homosexualité, Paris, PUF.

Commaille J, Martin C (2000) : «Pacs : la repolitisation du privé », in R. Mouriaux (Ed), L'année sociale. Paris, édition Syllepse.

Déchaux JH. (1995), «Orientations théoriques en sociologie de la famille : autour de cinq ouvrages récents », Revue française de sociologie, XXXVI, 525-550.

Dekeuwer-Défossez F (1999) : Rénover le droit de la famille. Propositions pour un droit adapté aux réalités et aux aspirations de notre temps. Rapport au Garde des Sceaux, Paris, La Documentation Française. 
Festy P (2000) : «Les débuts du Pacs », Population et sociétés, n? 355, mars.

Gélard P. (1999) "Rapport sur le Pacte civil de solidarité au nom de la commission des Lois du Sénat ", Rapports du Sénat n? 258.

Giddens A. (1992): The Transformation of Intimacy. Sexuality, Love and Eroticism in Modern Societies. Cambridge, Polity Press.

Gokalp C. (1981): Quand vient l'âge des choix. Enquête auprès des jeunes de 18 à 25 ans : emploi, résidence, mariage. Paris, PUF, INED “ Travaux et documents, cahier n? 95 ”.

Hauser J., and Huet Weiller D. (1989)Traité de droit civil, Paris, LGDJ.

Jenson J. (1997) : “Fated to Live in Interesting Times : Canada's Changing Citizenship Regimes “. Canadian Journal of Political Science, vol. 30, 4, p. 627-644.

Kaufmann J-C. (1993), Sociologie du couple. Paris. PUF, «Que sais-je ? ».

Le Bras H. (1991) : Marianne et les lapins. L'obsession démographique. Paris. Olivier Orban.

Léridon H., Villeneuve-Gokalp C. (1994), Constance et inconstances de la famille. Biographies familiales des couples et des enfants. Paris, INED, collection « Travaux et documents », cahier n? 134.

Martel F. (2000), “Le Pacs, un an après”, Le Monde des débats, n? 17, septembre.

Martin C. (1997), L’après-divorce. Lien familial et vulnérabilité. Presses universitaires de Rennes.

Martin C. (1998), «Politiques sociales et monoparentalité. Evolution de l'action publique en France et au Royaume-Uni », Solidarité, santé, Etudes statistiques, Paris, Ministère des affaires sociales, n? 2-3, p. 125-138.

Martin C. (1999), «Les situations monoparentales : des familles vulnérables », Après-demain, n? 12, mars.

Meulders-Klein M.T. (1999), La personne, la famille et le droit, Bruxelles, Paris, Bruylant/LGDJ.

Neyrand G. (1994), «La résidence alternée de l'enfant : un hiatus entre les parents et la justice », Recherches et prévisions, n? 35, 1-18.

Murat P. (2000), Le pacs, analyse juridique, in Actes du colloque "Pacs; mode d'emploi", Ecole Nationale de la Magistrature/Barreau de Grenoble (roneo).

Prioux F. (2000) : “L'évolution démographique récente en France ”. Population, 3, 441-476.

Rabin B (1992) : «De plus en plus de naissances hors mariage ». Economie et statistiques, n? 251, 3-13.

Revue française des affaires sociales (1983), n? spécial «Recherches et familles », n? 4.

Roussel L. (1978) : “La cohabitation juvénile en France ”, Population, 1, 15-42.

Roussel L (1989) : La famille incertaine, Paris, Odile Jacob.

Rubellin-Devichi J. (1986) Les concubinages, Lyon, Ed. du CNRS.

Schiltz M-A. (1997): "Parcours de jeunes homosexuels dans le contexte du VIH/ la conquête d'un mode de vie ", Population, 6, 1485-1538. 
Singly (de) F. (1993), Sociologie de la famille contemporaine, Paris, Nathan, collection "128".

Singly (de) F. (1996) : Le soi, le couple et la famille, Paris, Nathan, coll. «Essais et recherches ».

Spira A., Bajos N et groupe ACSF (1993) :Les comportementss sexuels en France . rapport au ministre de la Recherche et de l'Espace. Paris, La Documentation Française.

Sullerot E. (1984), Pour le meilleur et sans le pire, Paris, Fayard.

Sullerot E. (1997) : Le grand remue-ménage. La crise de la famille. Paris, Fayard.

Théry I. (1993), Le démariage. Justice et vie privée. Paris, Odile Jacob.

Théry I. (1997) “Le contrat d'union sociale en question”, Esprit, octobre.

Théry I. (Ed) (1998), Couple, filiation et parenté aujourd'hui, Paris, Odile Jacob et La Documentation Française.

Théry I. (1999) “Pacs, sexualité et différence des sexes ”, Esprit, octobre.

Théry I. (2000) : “La mixité, figure nouvelle de l'égalité ", La revue de la Confédération française démocratique du travail, n? 8, 9-18.

Toulemon L (1996) : «La cohabitation hors mariage s'installe dans la durée ». Population, 3, 675-716.

Villeneuve-Gokalp C. (1997), «Vivre en couple chacun chez soi », Population, 5, 1059-1082.

Villeneuve-Gokalp C. (1999), « La double famille des enfants de parents séparés », Population, 1, 9-36.

\section{NOTES}

i. The marriage rate was 7.6 compared to 8.2 in 1949 .

ii. Cohabitants can no longer claim for the supplementary fiscal deduction allowed for the first child of a non-married parent. In that sense, they are encouraged to marry, and even more so if they are high earners, many children and there is a big difference between the salaries of the partners.

iii. More precisely, the average age at the first marriage was 28.5 years for men born in 1965 (compared to 24.5 years for men born in 1948) and 26.6 for women born in 1965 (compared to 22.6 for women born in 1950).

iv. Coming out has been quite important in the battle for the city council of Paris, where most homosexuals live.

v. The institutionalization of the family associations as official partners for the authorities was established in 1942 (during the "régime de Vichy") and confirmed in 1945. From this period, the federation of these movements, the "Union nationale des associations familiales" has been represented in all the boards of the "Caisses d'allocations familiales" (the administration of the family "branch" of our social security system), but also in many other institutions, like the "Conseil économique et social" or the commission that controls the quality of television programmes.

vi. France has been condemned over this law in January 2000 by the European Court of Human Rights; Mazurek v France. 
vii. Six months earlier, Théry had suggested another solution which she considers more complete and satisfying : "concubinage" for all cohabiting couples plus registered partnership for same-sex couples as in the northern European countries (Théry, 1997). This was rejected by the homosexual movement as "communautarism", so she did not maintain it in the official report.

viii. For example, Joël Métreau, in a paper of the homosexual journal "Têtu" in October 2000 presenting the results of a national survey about public opinion on homosexuality suggests that 19,054 pacs were registered by the end of June 2000, but these data are not official. See also Martel (2000).

ix. One of the fields where this anxious and even dramatic approach has been mainly developed as a so called "decline" or "crisis" of family is the field of civil law (Malaurie, Cornu). This traditional characteristic of jurists has been more or less hidden during the 1980s because of the influence of the French civilist, Jean Carbonnier. But recently he began himself to be more and more critical about social change and especially legal change (Carbonnier, 1999) 